\title{
PEMANFAATAN MEDIA DIGITAL OLEH GURU PADA SISWA KELAS X DI SMA NEGERI 1 PLERET GUNA MENINGKATKAN HASIL BELAJAR PKn SECARA EFISIEN
}

\author{
Kholif Hidayat \\ Mahasiswa Pendidikan Pancasila dan Kewarganegaraan, Universitas Cokroaminoto Yogyakarta \\ Jl. Perintis Kemerdekaan, Gambiran, Pandeyan, Umbulharjo, Kota Yogyakarta 55161 \\ Email: kholifhidayat.smp@gmail.com
}

\begin{abstract}
ABSTRAK
Tujuan penelitian ini untuk: (1) Untuk mengetahui hasil belajar PKn siswa ketika guru menggunakan media pembelajaran berbasis digital, (2) Untuk mengetahui bagaimana cara guru memanfaatkan media digital dalam proses pembelajaran, (3) Untuk mengetahui kendala apa saja yang dihadapi guru dalam menggunakan media digital dalam proses pembelajaran PKn.

Penelitian ini secara spesifik lebih diarahkan pada desain penelitian deskriptif kualitatif. Penelitian deskriptif kualitatif berusaha untuk menuturkan pemecahan masalah yang ada sekarang berdasarkan data-data. Maka dalam penelitian ini, peneliti akan menggunakan desain penelitian deskriptif kualitatif untuk menjelaskan tentang pemanfaatan media digital oleh guru pada siswa kelas X SMA N 1 Pleret guna meningkatkan hasil belajar siswa secara efisien. Teknik pengumpulan data yang digunakan dalam penelitian ini adalah observasi, wawancara dan dokumentasi.

Adapun hasil penelitian menunjukkan bahwa, pemanfaatan media pembelajaran berbasis digital dalam meningkatkan hasil belajar PKn di SMA N Pleret sebagai berikut: Secara umum pemanfaatan media pembelajaran yang digunakan guru di SMA N 1 Pleret cukup baik dan maksimal. Untuk media pembelajaran PKn sudah menggunakan LCD meskipun guru harus membawa laptop sendiri serta dalam ulangan harian maupun ujian tengah semester (UTS) ratarata hasil belajar PKn diatas nilai KKM, adapun nilai KKM di SMA N 1 Pleret pada mata pelajaran PKn adalah 7,5.

Kata kunci: Pemanfaatan media digital, guru, hasil belajar, PKn, siswa SMA.
\end{abstract}

\section{PENDAHULUAN}

Pemerintah mendorong guru untuk mampu menguasai teknologi serta mengikuti perkembangan ilmu pengetahuan dan teknologi. Hal itu untuk mengimbangi cepatnya perubahan sosial dan perkembangan teknologi. Guru dituntut untuk membekali anak didik dengan pengetahuan dan pendidikan yang mampu menjawab persoalan-persoalan dimasa depan. Oleh karena itu, anak didik tak lagi sekedar mampu menghafal pelajaran. Lebih dari itu, siswa mesti diajarkan untuk menghayati dan menginternalisasi materi yang mereka pelajari. Demi mendukung percepatan penguasaan teknologi guru, pemerintah mensosialisasikan agar guru melek literasi, antara lain literasi bahasa, numerik, digital, dan budaya.

Guru yang menguasai teknologi masih sedikit. Sebagian besar guru di pedesaan masih terbatas untuk bisa menguasai teknologi karena keterbatasan infrastruktur. Tuntutan penguasaan teknologi tak serta merta mengharuskan guru mengajar bermodal teknologi tinggi. Pendekatan- 
pendekatan sederhana yang disesuaikan dengan lingkungan sosial dan budaya setempat mesti digunakan guru untuk menyampaikan materi pembelajaran secara kreatif.

Penerapan teknologi juga berlaku di dunia pendidikan. Kita bisa memperhatikan teknikteknik inovasi pembelajaran yang ada di dunia pendidikan Indonesia dewasa ini, hal ini merupakan salah satu geliat pertumbuhan pengetahuan yang terjadi di dunia pendidikan. Guru dituntut untuk menjadi terdepan dalam penguasaan teknologi sebagai wujud akselerasi pengetahuan yang mutlak harus ditransfer kepada generasi penerus. Hal ini untuk menghindari terjadi gap yang telalu lebar antara penguasaan pengetahun guru dengan penguasaan pengetahuan anak didiknya. Guru yang pada awalnya sebagai sumber, sekarang bergeser essensi-nya menjadi seorang fasilitator yang harus mampu menjembatani antara perkembangan pengetahuan dan teknologi dengan anak didiknya. Hal ini harus memicu para guru agar mau dan mampu berkompetisi dalam alur perkembangan ilmu pengetahuan dan teknologi yang terus menerus maju. Jika perlu, guru dipaksa belajar dan terus belajar agar mereka tidak tertinggal dari ilmu pengetahuan dan informasi yang berkembang pada lingkungan anak didiknya. Hal yang perlu dilakukan mulai sekarang adalah meningkatkan kualitas guru, pendidik dan tenaga kependidikan untuk bisa mengimbangi perkembangan teknologi dan informasi, agar tujuan mulia pendidikan dapat tercapai secara efisien. Kenapa harus menunggu hari esok jika ternyata apa yang ada dalam lingkungan disekitar sudah tersedia? Tersedia disini bukan dalam arti lengkap atau mencukupi kebutuhan pembelajaran, tetapi menunjuk kearah pemanfaatan secara maksimal segala resource yang sebenarnya sudah tersedia walaupun mungkin belum kita sadari sepenuhnya.

Peserta didik bukan sekedar obyek dalam pembelajaran yang "diam dan duduk" saja, akan tetapi dapat menjadi subjek yang ikut berinteraksi langsung dalam pembelajaran. Ini menunjukkan bahwa model-model pembelajaran yang konvensional harus tahap demi tahap digeser dengan model pembelajaran yang mengarah pada keaktifan siswa (student centered). Disinilah perumpaman bahwa teknologi itu laksana sebuah pisau bermata dua. Satu sisi jika perkembangan teknologi informasi dapat diikuti maka segalanya akan terasa mudah dan dapat membantu memperingan tugas dan beban guru. Sebaliknya teknologi akan menjadi sebuah malapetaka bagi guru manakala tidak mampu mengikuti perkembangan teknologi informasi.

Pemanfaatan media digital dalam bidang pendidikan dapat menunjang pembelajaran yang kini merupakan suatu keharusan. Tetapi, yang lebih penting adalah untuk meningkatkan penguasaan teknologi informasi dan komunikasi baik bagi guru maupun siswa sebagai bekal hidup di era teknologi yang terus berubah dan berkembang.

Dalam konteks pembelajaran, pemanfaatan dan pemberdayaan media digital, termasuk teknologi multimedia, dapat meningkatkan efektivitas dan efisiensi pembelajaran, yang 
diharapkan dapat memberikan kepuasan public dengan memberikan layanan yang prima dengan hasil sesuai dengan standar dan tujuan yang diharapkan. Jika pada masa lalu ada anggapan bahwa pembelajaran tidak terlalu perlu menggunakan media digital, pada era saat ini penggunaan media digital merupakan suatu keharusan.

Media pembelajaran merupakan bagian tak terpisahkan dari kegiatan pembelajaran di sekolah. Pemanfaatan media juga merupakan upaya kreatif dan sistematis untuk menciptakan pengalaman yang dapat membantu proses belajar siswa. Hal ini dikarenakan media berperan sebagai alat perangsang belajar dan dapat menumbuhkan motivasi belajar sehingga siswa tidak mudah bosan dalam mengikuti proses belajar mengajar. Beberapa contoh dan jenis media pembelajaran diantaranya adalah:

1. Media visual adalah media yang hanya dapat dilihat seperti gambar, grafik, poster dan sebagainya.

2. Media audio adalah media yang digunakan untuk menyampaikan pesan dimana fokus penyampainnya menggunakan aspek pendengaran seperti radio, tape recorder, laboratorium bahasa.

3. Media audio visual adalah media gabungan antara audio dan visual seperti televisi, film, komputer. (Azhar Arsyad, 2014:91)

Pengertian media pembelajaran adalah alat bantu pada proses belajar mengajar baik di dalam maupun di luar kelas, lebih lanjut dijelaskan bahwa media pembelajaran adalah komponen sumber belajar atau wahana fisik yang mengandung materi instruksional di lingkungan siswa yang dapat merangsang siswa untuk belajar. (Azhar Arsyad, 2014:3).

Media pembelajaran dapat dipahami sebagai segala sesuatu yang dapat menyampaikan atau menyalurkan pesan dari sumber secara terencana, sehingga terjadi lingkungan belajar yang kondusif dimana penerimanya dapat melakukan proses belajar mengajar secara efisien dan efektif (Rayanda asyar, 2012:8). Media pembelajaran adalah segala sesuatu yang dapat digunakan untuk menyampaikan pesan atau informasi dalam proses belajar mengajar sehingga dapat merangsang perhatian dan minat siswa dalam belajar. (Azhar Arsyad, 2014:10).

Belajar adalah sesuatu kegiatan yang tidak dapat dipisahkan dari kehidupan manusia. Kegiatan belajar dapat berlangsung dimana-mana, misalnya di lingkungan keluarga, di sekolah dan di masyarakat, baik disadari maupun tidak disadari, disengaja atau tidak disengaja. Menurut Jenkins dan Unwin Uno,(2011:17) mengatakan bahwa hasil belajar adalah pernyataan yang menunjukkan tentang apa yang mungkin dikerjakan siswa sebagai hasil dari kegiatan belajarnya. Jadi hasil belajar merupakan pengalaman-pengalaman belajar yang diperoleh siswa dalam bentuk kemampuan-kemampuan tertentu. 
Menurut Bloom (dalam Suprijono 2013:6) hasil belajar mencakup kemampuan kognitif, afektif dan psikomotorik. Kemampuan kognitif terdiri dari knowledge (pengetahuan, ingatan); comprehension (pemahaman, menjelaskan, meringkas, contoh); application (menerapkan); analysis (menguraikan, menentukan hubungan); synthesis (mengorganisasikan, merencanakan); dan evaluating (menilai). Kemampuan afektif terdiri dari receiving (sikap menerima); responding (memberikan respon), valuing (nilai); organization (organisasi); characterization (karakterisasi). Kemampuan psikomotorik meliputi initiatory (inisiatif), pre-rountie, dan rountinized. Hasil belajar merupakan pencapaian bentuk perubahan perilaku yang cenderung menetap dari ranah kognitif, afektif, dan psikomotoris dari proses belajar yang dilakukan dalam waktu tertentu. Berdasarkan pernyataan para ahli diatas peneliti dapat menyimpulkan bahwa hasil belajar adalah suatu hasil yang diperoleh siswa setelah siswa tersebut melakukan kegiatan belajar mengajar serta bukti keberhasilan yang telah dicapai siswa dengan melibatkan aspek kognitif, afektif dan psikomorik. (Jihad dan Haris, 2012:14).

Pada dasarnya pembelajaran yang efektif dan efisien tidak mungkin lepas dari kemampuan dan keterampilan seorang guru (pendidik) bagaimana dia dapat mengimplementasikan ilmunya dalam proses interaksi edukatif. Kemantapan penggunaan metode mengajar, pengelolaan kelas, pengoptimalan situasi dan kondisi berlangsungnya proses belajar mengajar hingga penggunaan media belajar. Efektivitas sebenarnya ditentukan dengan menetapkan sampai sejauh mana Kegiatan Belajar Mengajar (KBM) mewujudkan tujuan yang harus dicapai sedangkan efisiensi diukur berdasarkan jumlah komponen yang digunakan untuk mewujudkan hasil yang ingin dicapai. Proses pembelajaran yang efektif dan efisien memiliki ciri-ciri sebagai berikut:

1. Berpusat pada siswa.

2. Interkasi edukatif antara guru dengan peserta didik.

3. Suasana yang demokratis, menyenangkan dan kreatif.

4. Penggunaan variasi metode mengajar.

5. Profesionalisme guru yang tinggi.

6. Bahan ajar yang sesuai dan bermanfaat.

7. Lingkungan yang kondusif.

8. Sarana belajar yang menunjang. (Ruangguru.co.id)

Manajemen Kelas Berbasis Teknologi (MKBT) adalah pengelola proses belajar mengajar di kelas secara efektif dan efesien dengan memanfaatkan teknologi komputerisasi. Disini guru berperan mempersiapkan, menata komponen fisik kelas, juga kesiapan siswa untuk menerima pelajaran. Pembelajaran tidak hanya terpakau pada kegiatan berbicara dan transfer pengetahuan saja, tetapi guru juga bertindak sebagai coaching (pelatih) dari pada hanya sekedar telling 
(pembicara) dan spending (penyalur) ilmu pengetahuan.Pemanfaatan teknologi informasi merupakan basis dalam mengembangkan pembelajaran di dalam kelas.

Guru yang inovatif sangat dibutuhkan dalam memanfaatkan teknologi sebagai alat bantu dalam pembelajaran yang dilakukannya, dimulai dari kegiatan merencanakan (planning), melaksanakan pembelajaran hingga penilaian hasil belajar dengan kreatifitas guru maka kegiatan pembelajaran bisa lebih efektif dan efisien yakni lebih cepat, lebih berhasil dan lebih bermanfaat bagi siswa. Dari hasil uraian diatas, pembelajaran yang efektif dan efisien adalah pembelajaran yang memungkinkan peserta didik untuk mencapai tujuan pembelajaran yang telah ditetapkan dengan penggunaan komponen pembelajaran secara maksimal.

\section{KAJIAN TEORI}

\section{Definisi media digital}

Media digital adalah media yang dikodekan dalam format mesin yang dapat dibaca (machine-readable). Konsep media digital adalah biner yaitu 0 dan 1 menggunakan gelombang diskrit. Media digital dapat dibuat, dilihat, didistribusikan, dimodifikasi dan bisa bertahan pada perangkat elektronik digital. Proses digital menggunakan logika Alogaritma. Program-program komputer dan perangkat lunak seperti citra digital, digital video; video games; halaman web dan situs web, termasuk media sosial; data dan database; digital audio, seperti mp3, mp4 dan e-buku adalah contoh media digital. Media digital sangat berbeda dengan media analog yang mengandalkan sistem manual seperti media cetak, buku cetak, surat kabar dan majalah yang masih bersifat tradisional seperti gambar, film tape audio dan lain-lain (Muhammad Yaumin, 2018:5).

Muhammad Yaumin memberi batasan media sebagai semua bentuk perantara yang digunakan oleh manusia untuk menyampaikan atau menyebarkan ide, gagasan, atau pendapat sehingga dapat sampai ke penerima yang dituju. Contoh-contoh Media digital antara Lain: Televisi, Radio, Film, Gambar yang di proyeksi, OHP, LCD dan lain-lain. (2018:134).

Dalam era modern kombinasi antara internet dan komputerisasi personal, menyebabkan media digital membawa dampak dan masalah dalam dunia penerbitan, jurnalistik, hiburan, pendidikan, perdagangan dan politik. Media Digital juga telah menimbulkan tantangan baru terutama bagi hukum yang melindungi hak cipta dan kekayaan intelektual, dalam gerakan konten terbuka di mana pencipta konten dengan sukarela menyerahkan sebagian atau seluruh hak-hak hukum mereka untuk pekerjaan mereka. Kini Media digital sudah memasuki sendi-sendi kehidupan masyarakat dan dampaknya telah terasa bagi masyarakat luas dan itu menunjukan bahwa media digital adalah awal sebuah era baru dalam sejarah industri yang disebut era 
Informasi, dan telah mengarah ke masyarakat paperless di mana semua produk inforamsi pada media yang diproduksi dan dikonsumsi berbasis komputer. Namun, tantangan menuju transisi media digital, termasuk produk undang-undang yang mengatur hak cipta, sensor, digital divide, adalah momok menuju era kegelapan digital (digital dark age) di mana media yang lebih tua menjadi tidak dapat diakses ke sistem baru atau tidak bisa diupgrade ke sistem informasi. Sedangkan media-media digital yang signifikan, luas dan kompleks telah memberi dampak pada masyarakat dan budayanya.

\section{Peran Guru dalam Pemanfaatan Media Digital}

Di zaman yang serba modern dan canggih ini, guru harus bisa mengikuti perkembangan zaman. Jika tidak, maka guru akan tertinggal jauh bahkan oleh peserta didiknya sendiri yang memang hidup di generasi milenial yang serba digital ini.Perkembangan gadget dan teknologi terbaru membuat anak-anak dapat mengakses apa saja kapan saja melalui gadget atau perangkat yang dimilikinya. Terkadang saat gurunya belum mengetahui teknologi terbaru, justru peserta didiknya sudah mengetahui bahkan sudah menggunakan aplikasi dan teknologi terbaru tersebut.Sebagai seorang guru tentu harus terus belajar dan belajar lagi termasuk dalam hal menggunakan teknologi dan aplikasi terbaru khususnya dalam pembelajaran. Seorang pendidik dituntut untuk bisa memanfaatkan teknologi termasuk penggunaan internet untuk hal yang positif.Jauhkan mindset (pola pikir) guru yang beranggapan bahwa faktor usia yang sudah lanjut sehingga menghalangi mereka untuk belajar. Padahal mereka mengetahui bahwa belajar itu sampai akhir hayat bukan hanya saat sudah menjadi guru kemudian berhenti untuk belajar.

Guru harus bisa memanfaatkan teknologi tersebut untuk proses belajar mengajar. Guru bisa mencari bahan ajar melalui internet, memanfaatkan soal secara online, memanfaatkan media sosial untuk pendidikan, dan masih banyak hal lain yang bisa dilakukan dalam hal pemanfaatan teknologi.Jika guru belum bisa menguasai kemajuan teknologi, maka cara terbaik adalah guru mau belajar dengan mengikuti berbagai pelatihan, workshop atau sejenisnya yang materinya membahas tentang penggunaan teknologi untuk pembelajaran.

\section{Hasil Belajar}

Belajar dan mengajar merupakan konsep yang tidak bisa dipisahkan. Belajar merujuk pada apa yang harus dilakukan seseorang sebagai subyek dalam belajar. Sedangkan mengajar merujuk pada apa yang seharusnya dilakukan seseorang guru sebagai pengajar. Dua konsep belajar mengajar yang dilakukan oleh siswa dan guru terpadu dalam satu kegiatan. Diantara keduanya itu terjadi interaksi dengan guru. Kemampuan yang dimiliki siswa dari proses belajar mengajar saja 
harus bisa mendapatkan hasil, bisa juga melalui kreatifitas seseorang itu tanpa adanya intervensi orang lain sebagai pengajar. Oleh karena itu, hasil belajar yang dimaksud adalah kemampuankemampuan yang dimiliki seorang siswa setelah ia menerima perlakuan dari pengajar (guru).Hasil belajar adalah kemampuan ketrampilan, sikap dan ketrampilan yang diperoleh siswa setelah ia menerima pengalaman belajar yang diberikan guru sehingga dapat menerapkan pengalaman belajarnya dalam kehidupan sehari-hari. (Helwiya, 2015:8).

Hasil belajar siswa dipengaruhi oleh kemampuan siswa dan kualitas pengajaran. Kualitas pengajaran yang dimaksud adalah profesional yang dimiliki oleh guru. Oleh karena itu, hasil belajar dipengaruhi oleh dua faktor dari dari dalam individu siswa berupa kemampuan personal (internal) dan faktor dari luar diri siswa yakni lingkungan. Dengan demikian hasil belajar adalah sesuatu yang dicapai atau diperoleh siswa berkat adanya usaha atau pikiran yang mana hal tersebut dinyatakan dalam bentuk penguasaan, pengetahuan dan kecakapan dasar yang terdapat dalam berbagai aspek kehidupan sehingga nampak pada diri individu penggunaan penilaian terhadap sikap, pengetahuan dan kecakapan dasar yang terdapat dalam berbagai aspek kehidupan sehingga nampak pada diri individu perubahan tingkah laku.

\section{Pembelajaran PKn}

Pendidikan Kewarganegaraan (Citizenship) merupakan mata pelajaran yang berfokus untuk membentuk warga negara supaya lebih memahami serta dapat melaksanakan segala hak dan kewajiban sebagai seorang warga negara. Pendidikan Kewarganegaraan mengalami perkembangan sejarah yang sangat panjang, yang dimulai dari Civic Education, Pendidikan Moral Pancasila, Pendidikan Pancasila dan Kewarganegaraan, sampai yang terakhir pada Kurikulum 2004 berubah namanya menjadi mata pelajaran Pendidikan Kewarganegaraan. Pendidikan Kewarganegaraan dapat diartikan sebagai wahana untuk mengembangkan dan melestarikan nilai luhur dan moral yang berakar pada budaya bangsa Indonesia yang diharapkan dapat diwujudkan dalam bentuk perilaku kehidupan sehari-hari peserta didik sebagai individu, anggota masyarakat dalam kehidupan berbangsa dan bernegara.Landasan PKn adalah Pancasila dan UUD 1945, yang berakar pada nilai-nilai agama, kebudayaan nasional Indonesia (Permendikbud No.22 Tahun 2006).

Tujuan Pembelajaran PKn, antara lain:

a. Berpikir secara kritis, rasional, dan kreatif dalam menangggapi isu kewarganegaraan.

b. Berpartisipasi secara bermutu dan bertanggungjawab, dan bertindak secara cerdas dalam kegiatan bermasyarakat, berbangsa, dan bernegara. 
c. Berkembang secara positif dan demokratis untuk membentuk diri berdasarkan pada karakter-karakter masyarakat Indonesia agar dapat hidup bersama dengan bangsa-bangsa lain.

d. Berinteraksi dengan bangsa-bangsa lain dalam percaturan dunia secara langsung dengan memanfaatkan teknologi informasi dan komunikasi. (Permendiknas Nomor 22 Tahun 2006)

Pembelajaran Secara Efisien

Kata efisien berarti "Hemat biaya tenaga dan waktu, mendapatkan hasil maksimal tanpa mengeluarkan banyak", Sedangkan definisi efisien adalah tepat atau sesuai untuk mengerjakan (menghasilkan) sesuatu (dengan tidak membuang-buang waktu, tenaga, biaya), mampu menjalankan tugas dengan tepat dan cermat, berdaya guna, bertepat guna. Jadi, pengertian efisien dalam pembelajaran merupakan cara belajar untuk mencapai tujuan yang maksimal dari yang diharapkan dan cara hemat biaya tenaga dan waktu, mendapatkan hasil maksimal tanpa mengeluarkan banyak.

Pembelajaran yang baik dan efisien adalah pembelajaran yang aktif, interaktif, kreatif, edukatif, dan menyenangkan. Untuk terjadinya hal tersebut dibutuhkan pemilihan strategi pembelajaran yang tepat. Strategi pembelajaran juga mengandung siapa melakukan apa dalam proses pembelajaran, bagaimana melaksanakan tugas pembelajaran, serta dimana kegiatan pembelajaran berlangsung. Strategi pembelajaran efisien adalah pola-pola umum kegiatan guru siswa dalam perwujudan kegiatan pembelajaran untuk mencapai kompetensi sebagai tujuan pembelajaran yang telah ditentukan, ditandainya dengan adanya perubahan yang membawa pengaruh, makna dan manfaat dalam kegiatan pembelajaran. Pengertian efisien dalam pembelajaran merupakan cara belajar untuk mencapai tujuan yang maksimal dari yang diharapkan dan cara hemat biaya tenaga dan waktu, mendapatkan hasil maksimal tanpa mengeluarkan banyak. Strategi pembelajaran efisien adalah pola-pola umum kegiatan guru siswa dalam perwujudan kegiatan pembelajaran untuk mencapai kompetensi sebagai tujuan pembelajaran yang telah ditentukan, ditandainya dengan adanya perubahan yang membawa pengaruh, makna dan manfaat dalam kegiatan pembelajaran. (Abdul Majid, 2013:25).

\section{METODE PENELITIAN}

Ditinjau dari jenis datanya pendekatan penelitian yang digunakan dalam penelitian ini adalah penelitian kualitatif. Adapun yang dimaksud penelitian kualitatif adalah penelitian yang berlandaskan pada filsafat postpositivisme, digunakan untuk meneliti pada obyek alamiah, (sebagai lawannya eksperimen) dimana peneliti adalah sebagai instrumen kunci, pengambilan 
sampel sumber data dilakukan secara gabungan (triangulasi), analisi data bersifat induktif atau kualitatif, dan hasil penelitian kualitatif lebih menekankan makna dari pada generalisasi. (Sugiyono, 2018:15).

Penelitian ini secara spesifik lebih diarahkan pada desain penelitian deskriptif kualitatif. Penelitian deskriptif kualitatif berusaha untuk menuturkan pemecahan masalah yang ada sekarang berdasarkan data-data. Maka dalam penelitian ini, digunakan desain penelitian deskriptif kualitatif untuk menjelaskan tentang pemanfaatan media digital oleh guru pada siswa kelas $\mathrm{X}$ SMA Negeri 1 Pleret guna meningkatkan hasil belajar siswa secara efisien.

Subjek atau informan adalah benda, hal atau orang tempat data untuk variabel melekat, dan yang dipermasalahkan.

a. Populasi Penelitian

Populasi penelitian ini adalah keseluruhan subjek penelitian. Dengan demikian yang menjadi populasi dari penelitian ini adalah semua siswa kelas X SMA Negeri 1 Pleret Bantul Yogyakarta yang berjumlah 180 siswa dan terdiri dari 6 kelas yaitu kelas X A, X B, X C, X D, X E, X F.

b. Sampel Penelitian

Populasi dalam penelitian ini berjumlah relative besar yaitu 180 siswa. Untuk itu dalam penelitian ini diambil sebagian dari populasi atau yang biasa disebut sampel. Sampel adalah sebagian atau wakil populasi yang diteliti.

Untuk sekedar ancer-ancer maka apabila subjek kurang dari 100, lebih baik sehingga penelitiannya merupakan penelitian populasi. Selanjutnya jika jumlah subjeknya besar dapat diambil antara $10-15 \%$ atau 20-25\% atau lebih. Sampel dari penelitian dapat diambil sebanyak $+25 \%$ dari 180 siswa yang jumlah sampelnya 30 siswa. Teknik yang digunakan untuk mencari sampel penelitian ini menggunakan Teknik Sampling Snowball berdasarkan metode sampling dimana sampel diperoleh melalui proses bergulir dari satu responden ke responden yang lainnya. Subyek penelitiannya adalah:

1) Kepala sekolah SMA Negeri 1 Pleret Bantul Yogyakarta.

2) Guru yang mengajar Pendidikan Kewarganegaraan di SMA Negeri 1 Pleret Bantul Yogyakarta.

3) Guru wali kelas X A di SMA Negeri 1 Pleret Bantul Yogyakarta.

4) Siswa kelas X A SMA Negeri 1 Pleret Bantul Yogyakarta. 


\section{Lokasi dan Waktu Penelitian}

a. Lokasi Penelitian

Tempat penelitian merupakan tempat dimana peneliti melakukan penelitian terutama dalam menangkap fenomena atau peristiwa yang sebenarnya terjadi dari objek yang diteliti dalam rangka mendapatkan data-data penelitian yang akurat. Dalam penelitian ini, tempat penelitian dilaksanakan di SMA Negeri 1 Pleret Bantul Yogyakarta yang beralamat di Kedaton, Pleret, Bantul, Yogyakarta 55791. Penelitian dilakukan di SMA Negeri 1 Pleret Bantul Yogyakarta dengan pertimbangan bahwa lokasi penelitian dekat jaraknya dengan domisili peneliti.

b. Waktu Penelitian

Penelitian dilaksanakan mulai tanggal 10 Mei 2019 sampai dengan 11 Juli 2019, yang meliputi kegiatan observasi, wawancara dan mengumpulkan data-data yang diperlukan.

Teknik pengumpulan data

Teknik Pengumpulan data merupakan langkah yang harus digunakan dalam mengadakan suatu penelitian agar memperoleh data sesuai dengan yang diharapkan dan dapat dipertanggung jawabkan. Teknik pengumpulan data yang digunakan dalam penelitian ini adalah observasi, wawancara dan dokumentasi.

a. Observasi

Observasi adalah cara-cara menganalisis dan pencatatan secara langsung dengan cermat dan sistematis bukan asal-asalan sajata terhadap fenomena-fenomena yang terjadi di lapangan yang akan diteliti secara langsung. Teknik observasi yang penyusunan digunakan adalah observasi lapangan, yakni teknik pengumpulan data dimana peneliti mengadakan pengamatan langsung tanpa alat terhadap gejala subjek yang diteliti.

Dengan metode ini peneliti dapat mengamati secara dekat yakni dengan mengamati secara langsung atau proses belajar mengajar khususnya pada pemanfaatan media digital pembelajaran yang digunakan oleh guru.

Tabel 1 Kisi-kisi Pedoman Observasi Pelaksanaan Penelitian

\begin{tabular}{|c|c|l|ll|}
\hline No & \multicolumn{1}{c|}{ Rumusan Masalah } & \multicolumn{1}{c|}{ Variabel } & \multicolumn{1}{c|}{ Indikator } & Rumusan Pertanyaan \\
\hline 1. & Pemanfaatan media & Bentuk & Pemanfaatan oleh & 1. Bagaimana \\
& pembelajaran jenis audio & pemanfaatan & guru dan & pemanfaatan media \\
& & media & pemahaman siswa & audio oleh guru? \\
& & pembelajaran & & 2. Bagaimana \\
& & jenis audio & pemahaman siswa \\
& & & melalui media \\
& & &
\end{tabular}




\begin{tabular}{|c|c|c|c|c|}
\hline & & & & $\begin{array}{l}\text { pembelajaran jenis } \\
\text { audio? }\end{array}$ \\
\hline 2. & $\begin{array}{l}\text { Pemanfaatan media } \\
\text { pembelajaran jenis visual }\end{array}$ & $\begin{array}{l}\text { Bentuk } \\
\text { pemanfaatan } \\
\text { media } \\
\text { pembelajaran } \\
\text { jenis visual }\end{array}$ & $\begin{array}{l}\text { Pemanfaatan oleh } \\
\text { guru dan } \\
\text { pemahaman siswa }\end{array}$ & $\begin{array}{l}\text { 1. Bagaimana } \\
\text { pemanfaatan media } \\
\text { visual oleh guru? } \\
\text { 2. Bagaimana } \\
\text { pemahaman siswa } \\
\text { melalui media } \\
\text { pembelajaran jenis } \\
\text { visual }\end{array}$ \\
\hline 3. & $\begin{array}{l}\text { Pemanfaatan media } \\
\text { pembelajaran jenis audio- } \\
\text { visual }\end{array}$ & $\begin{array}{l}\text { Bentuk } \\
\text { pemanfaatan } \\
\text { media } \\
\text { pembelajaran } \\
\text { jenis audio- } \\
\text { visual }\end{array}$ & $\begin{array}{l}\text { Pemanfaatan oleh } \\
\text { guru dan } \\
\text { pemahaman siswa }\end{array}$ & $\begin{array}{l}\text { 1. Bagaimana } \\
\text { pemanfaatan media } \\
\text { audio-visual oleh } \\
\text { guru? } \\
\text { 2. Bagaimana } \\
\text { pemahaman siswa } \\
\text { melalui media } \\
\text { pembelajaran audio- } \\
\text { visual? }\end{array}$ \\
\hline 4. & $\begin{array}{l}\text { Pemanfaatan media } \\
\text { pembelajaran jenis } \\
\text { multimedia }\end{array}$ & $\begin{array}{l}\text { Bentuk } \\
\text { pemanfaatan } \\
\text { media } \\
\text { pembelajaran } \\
\text { jenis } \\
\text { multimedia }\end{array}$ & $\begin{array}{l}\text { Pemanfaatan oleh } \\
\text { guru dan } \\
\text { pemahaman siswa }\end{array}$ & $\begin{array}{l}\text { 1. Bagaimana } \\
\text { pemanfaatan media } \\
\text { multimedia oleh } \\
\text { guru? } \\
\text { 2. Bagaimana } \\
\text { pemahaman siswa } \\
\text { melalui media } \\
\text { pembelajaran jenis } \\
\text { multimedia? }\end{array}$ \\
\hline
\end{tabular}

b. Wawancara

Wawancara merupakan suatu bentuk komunikasi verbal atau percakapan seseorang dengan orang lain yang bertujuan untuk memperoleh informasi. Metode wawancara digunakan untuk memperoleh data secara langsung kepada sumber data terkait. 
Pada hakikatnya wawancara merupakan kegiatan untuk memperoleh informasi sebanyak-banyaknya, maka kemahiran peneliti dalam proses wawancara dengan responden sangat penting. Wawancara dalam penelitian ini dilakukan dengan pertanyaan yang openended dan mengarah pada kedalaman informasi, serta dilakukan dengan cara yang tidak secara formal terstruktur, guna menggali pandangan subjek yang diteliti tentang banyak hal yang sangat bermanfaat untuk menjadi dasar bagi penggalian informasi yang lebih mendalam lagi.

Fungsi metode ini adalah untuk memperoleh data terhadap pemanfaatan media digital dalam pembelajaran oleh guru kepada siswa.Dalam hal ini yang diwawancarai adalah : kepala sekolah SMA Negeri 1 Pleret, guru mata pelajaran Pendidikan Kewarganegaraan, dan siswa kelas X A SMA Negeri 1 Pleret Bantul Yogyakarta.

Tabel 2. Kisi-kisi Pedoman Daftar Wawancara Tentang Pemanfaatan Media Digital

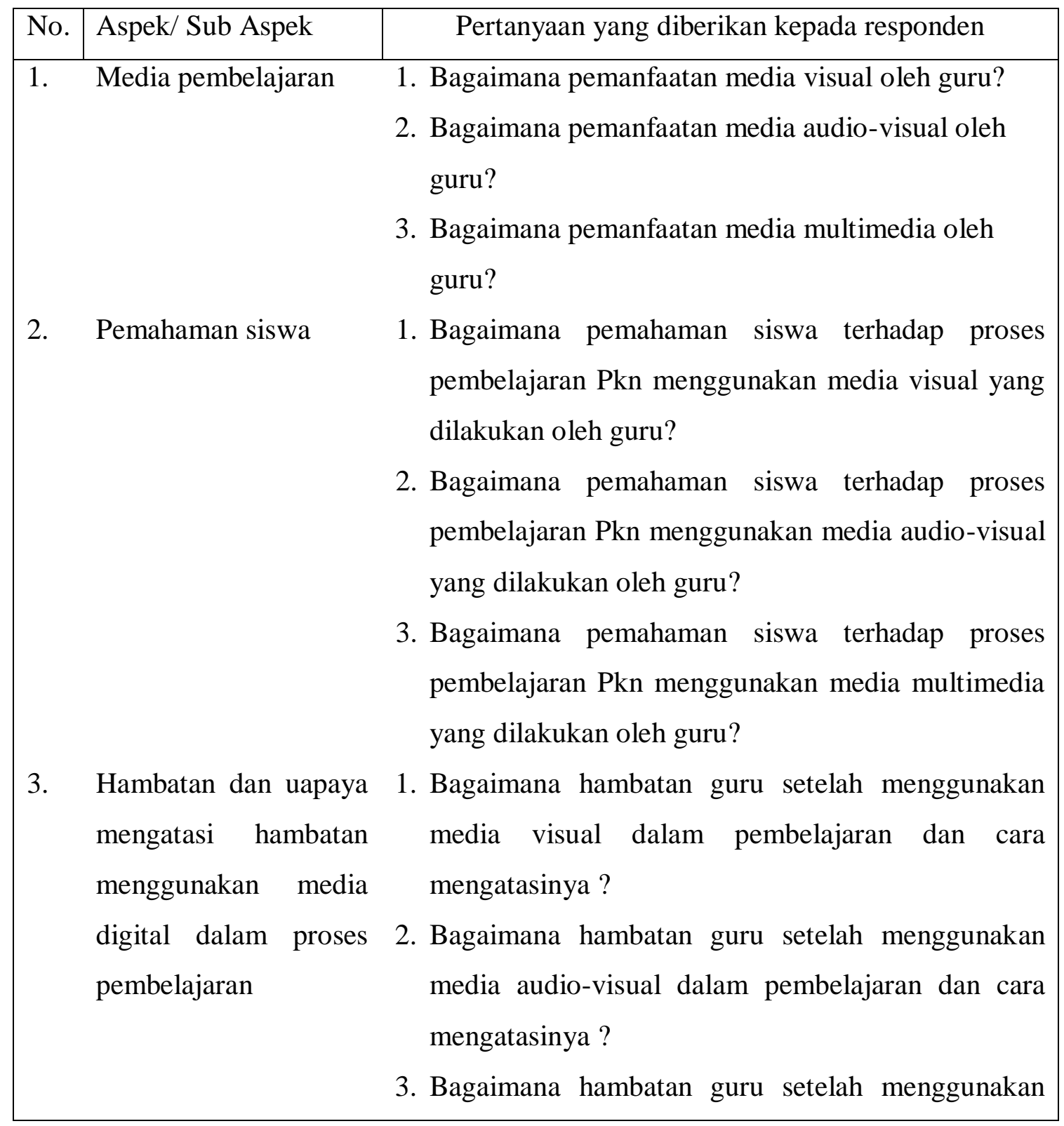


media multimedia dalam pembelajaran dan cara mengatasinya?

c. Dokumentasi

Dokumentasi adalah mencari data mengenai hal-hal atau variabel yang berupa objek yang dapat dilihat, yaitu bersumber dari tulisan (paper), tempat (place), dan kertas atau orang (people). Lebih jelas metode dokumentasi adalah cara pengumpulan data dengan cara meneliti dokumen-dokumen yang ada hubungannya dengan objek peneliti. Metode ini digunakan untuk menghimpun data dokumen khususnya pada Rencana Pelaksanaan Pengajaran (RPP).

Tabel 3. Kisi-kisi Analisis Pedoman Dokumen Rencana Pelaksanaan Pembelajaran.

\begin{tabular}{|c|c|c|c|}
\hline No. & Aspek/Sub aspek & $\begin{array}{c}\text { Jumlah } \\
\text { item }\end{array}$ & $\begin{array}{c}\text { Nomor } \\
\text { item }\end{array}$ \\
\hline 1. & Mata pelajaran & & \\
\hline 2. & Indikator pencapaian kompetensi & & \\
\hline 3. & Judul atau sub judul & & \\
\hline 4. & Sumber belajar & & \\
\hline 5. & Media pembelajaran & & \\
\hline 6. & Pendekatan pembelajaran & & \\
\hline 7. & Kegiatan pembelajaran & & \\
\hline 8. & Penilaian & & \\
\hline
\end{tabular}

d. Teknik analisis data

Analisis data adalah proses mencari dan menyusun secara sistematis data yang diperoleh dari hasil observasi, wawancara, dan dokumentasi, dengan cara mereduksi data (data reduction), menyajikan data (data display), dan penarikan kesimpulan (verification) sehingga mudah dipahami oleh peneliti dan orang lain. 


\section{PEMBAHASAN}

Media merupakan komponen yang sangat penting dalam proses pembelajaran. Keberhasilan seorang guru dalam menyampaikan materi pelajaran sebagian besar dipengaruhi oleh media. Namun, pendidik atau yang sering disebut guru juga merupakan faktor yang tidak kalah penting dalam pendidikan karena guru bertanggung jawab terhadap peserta didiknya atas pendidikan yang berlangsung. Keduanya saling berkaitan. Untuk menunjang profesinya sebagai guru harus mempunyai beberapa kompetensi salah satunya kompetensi profesional. Guru dalam mengajar harus mampu memanfaatkan media pembelajaran. Selain itu guru yang profesional dituntut dengan sejumlah persyaratan, antara lain : memiliki kualifikasi pendidikan yang memadai, memiliki kompetensi keilmuan sesuai dengan bidang yang ditekuninya, memiliki kemampuan berkomunikasi yang baik dengan anak didiknya, mempunyai jiwa kreatif dan produktif, mempunyai etos kerja dan komitmen tinggi terhadap profesinya, dan selalu melakukan pengembangan diri secara terus menerus. Hal-hal tersebutlah yang nantinya sangat menentukan keberhasilan guru dalam prosespembelajaran.

Untuk keperluan pelaksanaan pembelajaran di kelas, perlu dibuat satuan pembelajaran. Satuan pembelajaran tersebut merupakan realisasi dari pengalaman belajar siswa yang telah ditentukan pada tahapan penentuan pengalaman belajar siswa. Komponen satuan pembelajaran meliputi:

1. Identitas mata pelajaran (nama mata pelajaran, kelas, semester, dan waktu atau banyaknya jam pertemuan yang dialokasikan).

2. Kompetensi dasar (yang hendak dicapai atau dijadikan tujuan).

3. Materi pokok (beserta uraiannya yang perlu dipelajari siswa dalam rangka mencapai kompetensi dasar).

4. Strategi pembelajaran (kegiatan pembelajaran secara konkret yang harus dilakukan oleh siswa dalam berinteraksi dengan materi pembelajaran dan sumber belajar untuk menguasai kompetensi dasar).

5. Media (yang digunakan untuk kegiatan pembelajaran).

6. Penilaian dan tindak lanjut (instrument dan prosedur yang digunakan untuk menilai pencapaian belajar siswa serta tindak lanjut hasil penilaian, misalnya remedi dan pengayaan).

7. Sumber bahan (yang digunakan dalam kegiatan pembelajaran sesuai dengan kompetensi dasar yang harus dikuasai). (Permendikbud Nomor 59 Tahun 2014).

Adapun dalam praktiknya pemanfaatan media pembelajaran dalam meningkatkan hasil belajar Pkn di SMA Negeri 1 Pleret sebagai berikut, Secara umum pemanfaatan media 
pembelajaran yang digunakan guru di SMA Negeri 1 Pleret cukup baik. Untuk media pembelajaran PKn sudah menggunakan LCD, gambar atau poster, video, film dan media lain yang berbasis digital meskipun guru harus membawa laptop sendiri.

Peran media pembelajaran memang sangat penting dalam pencapaian hasil belajar siswa. Tetapi, tidak semua materi pelajaran mengharuskan menggunakan media pembelajaran yang khusus. Seperti mata pelajaran PKn yang materinya menekankan pada sikap atau tingkah laku sesuai dengan aturan perundangan. Selain media elektronika juga digunakan media pembelajaran yang sederhana. Pemakaian media tersebut disesuaikan dengan materi yang diajarkan. Misalnya ketika guru menjelaskan tentang pahlawan beliau menggunakan gambar atau poster dan gambar berbentuk digital yang ditayangkan menggunakan LCD proyektor sebagai media, hal ini disampaikan oleh Heri Widayati, S.Pd selaku guru mata pelajaran PKn.

Dalam pembelajaran terdapat dua proses yang saling keterkaitan dan tidak dapat dipisahkan satu sama lain yaitu proses belajar dan proses mengajar. Proses belajar dapat terjadi setiap saat tidak terbatas, tempat dan waktu serta terlepas dari ada yang mengajar atau tidak. Proses belajar terjadi karena adanya interaksi individu dengan lingkungannya. Poses mengajar merupakan kegiatan atau proses yang terarah dan terencana yang mengusahakan agar terjadi proses belajar pada diri seseorang.

Dalam pendidikan formal interaksi antara guru dan peserta didik perlu adanya alat penunjang dalam melakukan proses pembelajaran, yaitu media pembelajaran. Media itulah yang nantinya dapat membantu guru mempermudah menyampaikan materi pelajaran kepada peserta didik. Sehingga pesan atau informasi yang terkandung dalam materi tersebut dapat diterima pesrta didik dengan baik.

Pada tingkat yang menyeluruh dan umum pemilihan media dapat dilakukan dengan mempertimbangkan faktor-faktor berikut:

1. Hambatan pengembangan dan pembelajaran yang meliputi faktor- faktor dana, fasilitas dan peralatan yang telah tersedia, waktu yang tersedia (waktu mengajar dan pengembangan materidan media), sumber-sumber yang tersedia (manusia dan material).

2. Persyaratan isi, tugas, dan jenis pembelajaran. Isi pelajaran beragam dari sisi tugas yang ingin dilakukan siswa, misalnya penghafalan, penerapan keterampilan, pengertian hubungan- hubungan, atau penalaran dan pemikiran tingkatan yang lebih tinggi. Setiap kategori pembelajaran itu menuntut perilaku yang berbeda-beda, dan dengan demikian akan memerlukan teknik dan media penyajian yang berbedapula.

3. Hambatan dari sisi siswa dengan mempertimbangkan kemampuan dan keterampilan awal, seperti membaca, mengetik dan menggunakan komputer, dan karakteristik siswalainnya. 
4. Pertimbangan lainnya adalah tingkat kesenangan (preferensi lembaga, guru, dan pelajar) dan keefektivan biaya. (Azhar Arsyad, 2014:2)

Guru dalam melaksanakan proses pembelajaran ada beberapa hambatan. Berdasarkan hasil penelitian yang telah dilakukan ditemukan bahwa guru mata pelajaran PKn di SMA Negeri 1 Pleret mempunyai beberapa kendala atau hambatan dalam proses pembelajaran, khususnya yang ada kaitannya dengan media pembelajaran. Adapun hambatan yang dihadapi guru dalam memanfaatkan media pembelajaran di antaranya adalah keterbatasan waktu dalam menyiapkan media pembelajaran berbasis digital.

Di dalam proses pembelajaran tingkat pemahaman anak tentu berbeda-beda. Ada anak yang dijelaskan sekali langsung paham dan ada juga anak yang mengalami kesulitan dalam memahami pelajaran. Hal itu yang membuat guru kesulitan dalam memilih media pembelajaran, sehingga guru dalam setiap pertemuan kegiatan proses belajar mengajar memanfaatkan media pembelajaran berbasis digital yang bervariasi.

Berbicara mengenai pendidikan tidak akan terlepas dari guru dan peserta didik. Keduanya merupakan komponen pokok dalam proses pembelajaran. Hubungan antara guru dengan peserta didik dalam pembelajaran terjalin melalui pemanfaatan media pembelajaran sebagai perantara. Namun dalam kenyataannya beberapa guru mengalami hambatan dalam memanfaatkan media pembelajaran. Baik dari guru itu sendiri maupun lingkungan sekitarnya. Adapun upaya yang dilakukan guru di SMA Negeri 1 Pleret dalam menghadapi hambatan dalam memanfaatkan media pembelajaran diantaranya menyiapkan media pembelajaran berbasis digital pada waktu luang dan libur. Selain itu, guru mata pelajaran PKn juga bekerjasama dengan guru mata pelajaran Elektronika dan guru mata pelajaran TIK (Teknologi Informasi dan Komunikasi).

Setiap guru memiliki strategi yang berbeda-beda dalam mengelola proses pembelajaran. Agar siswa fokus terhadap pelajaran yang diberikan, guru membuat media yang semenarik mungkin. Dengan memanfaatkan media digital guru mampu membuat suasana kegiatan belajar mengajar menjadi menarik dan siswa menjadi fokus untuk mengikuti proses pembelajaran.

\section{SIMPULAN}

Berdasarkan hasil penelitian yang dilaksanakan di SMA Negeri 1 Pleret tentang pemanfaatan media digital oleh guru pada siswa kelas X untuk meningkatkan hasil belajar Pendidikan Kewarganegaraan (PKn) secara efisien dapat diambil beberapa kesimpulan. Kesimpulan tersebut sebagai berikut:

1. Sesuai dengan rumusan masalah, pemanfaatan media digital oleh guru pada siswa kelas $X$ SMA N 1 Pleret untuk meningkatkan hasil belajar Pendidikan Kewarganegaraan secara 
efisien, kesimpulannya adalah bahwa dalam pelaksanaan pembelajaran PKn yang dilaksanakan oleh guru pada siswa kelas X sudah menerapkan dan memanfaatkan media pembelajaran yang berbasis digital. Pelaksanaan pembelajaran yang dilaksanakan dalam mata pelajaran Pendidikan Kewarganegaraan (PKn) menggunakan metode pembelajaran yang bervariasi antara lain menggabungkan metode diskusi dengan gambar, video dan film sehingga siswa cenderung lebih aktif dalam mengikuti proses kegiatan belajar mengajar. Hal ini, membuat hasil belajar mata pelajaran Pendidikan Kewarganegaraan (PKn) cenderung meningkat karena dalam kegiatan proses belajar mengajar siswa aktif dan lebih konsentrasi dalam mengikuti pelajaran.

2. Kendala guru dalam menggunakan media digital dalam pelaksanaan pembelajaran PKn adalah kendala yang berasal dari sekolah dan dari kondisi siswa itu sendiri. Faktor yang menjadi kendala, berasal dari sekolah antara lain; penyampaian materi, keterbatasan waktu meyiapkan materi karena guru PKn yang ada di SMA Negeri 1 Pleret hanya ada dua guru yang dibagi waktu mengajarnya disemua kelas dan waktu pembelajaran PKn yang hanya dua jam pelajaran dalam satu minggu, kemudian kendala yang berasal dari siswa sendiri antara lain faktor lingkungan pergaulan siswa di luar sekolah yang sering bergaul dengan teman yang tidak sekolah sehingga berdampak pada pola tingkah laku siswa tersebut ketika berada di lingkungan kelas dan pengaruh negatif teknologi informasi yang tidak tersaring dengan baik serta kurangnya perhatian orang tua terhadap perkembangan siswa sehingga menjadikan siswa semakin mudah mengikuti arus negatif dalam lingkungan sekolah dan masyarakat.

3. Dampak setelah guru menerapkan media digital sebagai sarana proses belajar mengajar adalah siswa cenderung aktif dan fokus mengikuti kegiatan pembelajaran PKn sehingga hasil belajar siswa dalam mata pelajaran PKn meningkat diatas $\operatorname{KKM}(7,5)$.

\section{SARAN}

Berdasarkan hasil penelitian ditemukan beberapa permasalahan yang belum terpecahkan, sehingga peneliti mengajukan beberapa saran. Saran tersebut sebagai berikut:

1. Peranan guru sangat dominan dalam meningkatkan hasil belajar siswa dan membentuk karakter siswa sehingga harus menempatkan dirinya sebagai panutan yang dapat memberi teladan serta sebagai motivator di lingkungan sekolah.

2. Guru lebih mengembangkan strategi pembelajaran yang kreatif sehingga dapat membuat siswa aktif belajar dan mempraktikkan nilai-nilai karakter yang dikembangkan dalam mata pelajaran Pkn selain meningkatkan hasil belajar Pkn. 
3. Meningkatkan hasil belajar siswa harus didukung semua pihak yang bersangkutan, terutama guru kelas dalam menerapkan model pembelajaran yang kreatif serta sarana prasarana yang memadai.

\section{DAFTAR PUSTAKA}

Ali, Muhammad. 2014. Guru Dalam Proses Belajar Mengajar. Bandung: Sinar Baru Algensindo. Arsyad, Azhar. 2014. Media Pembelajaran. Jakarta: Rajawali Pers.

Asyhar, Rayandra. 2013. Kreatif Mengembangkan Media Pembelajaran. Yogyakarta: Referensi. Eprints.uny.ac.id

Hamzah Uno. 2011. Teori Motivasi dan Pengukurannya: Analisis dibidang pendidikan. Jakarta: Bumi Aksara.

Helwiya. 2015. Hasil Belajar Siswa. Surabaya: Kresna Bina Insan Prima.

Jihad dan Haris. 2013. Evaluasi Pembelajaran. Yogyakarta: Multi Pressindo.

Kosasih, A dan R. Angkowo. 2007. Optimalisasi Media Pembelajaran. Jakarta: Grasindo.

Majid, Abdul. 2013. Strategi Pembelajaran. Bandung: Rosdakarya.

Mulyasa. 2007. Menjadi Guru Profesional. Bandung: Remaja Rosdakarya Offset.

Permendikbud Nomor 22 Tahun 2006

Permendikbud Nomor 59 Tahun 2014

Ruangguru.co.id

Sudjana.2017. Penilaian Hasil Belajar Proses Belajar Mengajar. Bandung: PT Remaja Rosdakarya.

Kurnia, H. (2014). PENGARUH KEAKTIFAN BERORGANISASI TERHADAP INDEKS PRESTASI KUMULATIF MAHASISWA UNIVERSITASCOKROAMINOTO YOGYAKARTA. Academy of Education Journal, 5(2). https://doi.org/10.47200/aoej.v5i2.120

Sugiyono. 2018. Metodelogi Penelitian Kualitatif dan Kuantitatif. Bandung: Alfabeta.

Suprijono. 2013. Cooperative Learning dan Aplikasi Paikem. Yogyakarta: Pustaka Pelajar.

Suyono. 2015. Implementasi Belajar dan Pembelajaran. Bandung: PT Remaja Rosdakarya 